\title{
The conceptual development of customer loyalty measurement: A proposed scale
}

Received (in revised form): 2nd September, 2002

\section{Rosalind McMullan}

is a lecturer in business strategy in the School of Marketing, Entrepreneurship and Strategy in the University of Ulster. Her teaching and research interests are in services marketing and management.

\section{Audrey Gilmore}

is a reader at the University of Ulster. Her teaching and research interests are in service marketing and management, SME marketing, competencies and networking. She has published in a variety of international journals on these themes. Much of her research has involved the development of qualitative methodologies for marketing studies. She is Joint Editor of the European Journal of Marketing and is currently the Academy of Marketing Regional Chair for Ireland.

Rosalind McMullan School of Marketing, Entrepreneurship \& Strategy, Faculty of Business and Management, University of Ulster at Jordanstown, Shore Road, Newtownabbey BT37 OQB, Northern Ireland.

Tel: +44 (0)2890 368904/ (0)2890 366397; Fax: $+44(0) 2890366868$; e-mail: wr.mcmullan@ulster.ac.uk

\begin{abstract}
This paper discusses the theoretical foundations for the measurement of a multiphase model of customer loyalty development. A hypothesis is specified and a methodology discussed which highlights the phases in the development of a scale to measure customer loyalty. Based on this a measurement scale has been developed. The scale is described and justified in terms of its validity and reliability. Finally, the stage is set for the planned use of the scale to measure the different phases of customer loyalty.
\end{abstract}

\section{INTRODUCTION}

The development of customer loyalty has become an important focus for marketing strategy in recent years, but the concept of customer loyalty remains relatively unexplored. While a number of studies has distinguished between the attitudinal and behavioural dimensions of loyalty, ${ }^{1}$ these have not adequately explored the complex interrelationships between the two dimensions, and the dynamic processes by which loyalty is initiated and sustained. This research builds on the work of Oliver ${ }^{2,3}$ by seeking to develop a scale for measuring customer loyalty. Furthermore, it seeks to use the scale to explore how the structure and strength of loyalty changes through four phases hypothesised by Oliver. ${ }^{4,5}$

It is important to gain a greater understanding of the dynamic multiphase processes of loyalty development for a number of reasons. In practical terms this knowledge could be used to segment customers according to their phase within the process, an implication being that marketing strategy should be adapted to the relationship-based needs of individual customers. Customers who are at a different phase in their relationship of the process may show differing levels of forbearance in the 
event of a service failure ${ }^{6,7}$ or increased competition $^{8}$ and may call for differentiated strategies.

The paper begins by summarising the main literature relating to customer loyalty and contextually positioning Oliver's model. ${ }^{9,10}$ From this, a hypothesis is developed that identifiable phases in the development of customer loyalty occur which reconcile the seemingly divergent behavioural and attitudinal dimensions of loyalty. Each phase of the process is then discussed including the characteristics of each phase. The methodology describes the development and validity measures of the scale.

\section{CUSTOMER LOYALTY}

The current focus on customer loyalty both academically and practically is fuelled by the debate on frequency programmes or loyalty programmes. ${ }^{11-14}$ Many frequency programmes offer differing levels of reward usually dependent upon the frequency and level of purchases. A problem with this approach is that customers focus on the rewards rather than product superiority or brand relevance. Frequency programmes often do not take into account which phase the customer is at within his or her development of loyalty. The differences between frequency and loyalty programmes lead to different tactics. Many programmes do not, however, reward loyalty based on the problems associated with developing appropriate strategies to reward and develop loyalty. These problems arise from the difficulty in defining and measuring the complex nature of customer loyalty.

The most widely accepted definition of loyalty is by Jacoby and Chesnut. ${ }^{15}$ They suggest that customer loyalty is the behavioural outcome of a customer's preference for a particular brand from a selection of similar brands, over a period of time, which, importantly is the result of an evaluative decision-making process.

Oliver states that previous customer loyalty research failed to provide a unitary definition and relied on two or three components, including cognition, affect and behavioural intention. ${ }^{16}$ His definition identifies the essential issues of commitment, preference and consistency while recognising the dynamic nature of the marketing environment and situational influences. He suggests that 'ultimate loyalty' exists if a customer remains loyal in the face of opportunities to switch to an alternative supplier. In contrast to existing research, there is no distinction between proactive loyalty and situational loyalty calculated by the frequency of purchase. ${ }^{17}$ Proactive loyalty occurs where a consumer frequently buys a brand and settles for no other substitute. Situational loyalty exists when the buyer purchases a brand for a special occasion. Therefore loyalty is not uniquely concerned with frequency and depth of purchases of one brand over another; rather the consumer may not have the need to buy a product or service regularly, only as the opportunity arises (for example, an annual holiday). Oliver warns, however, that many providers, because of the nature of product category or consumer disinterest, cannot achieve loyalty. ${ }^{18}$

There is a consensus of opinion that the first three phases lead to a deeply held commitment, which predicts that consumers become loyal, first in a cognitive sense, then later an affective sense and thirdly a conative manner. ${ }^{19-22}$ The three states may not, as dissonance literature would suggest, be in synchrony or linearly related. One aim of this research will be to test this issue. The fourth phase, as suggested by Oliver, ${ }^{23,24}$ relates to action loyalty, which provides 


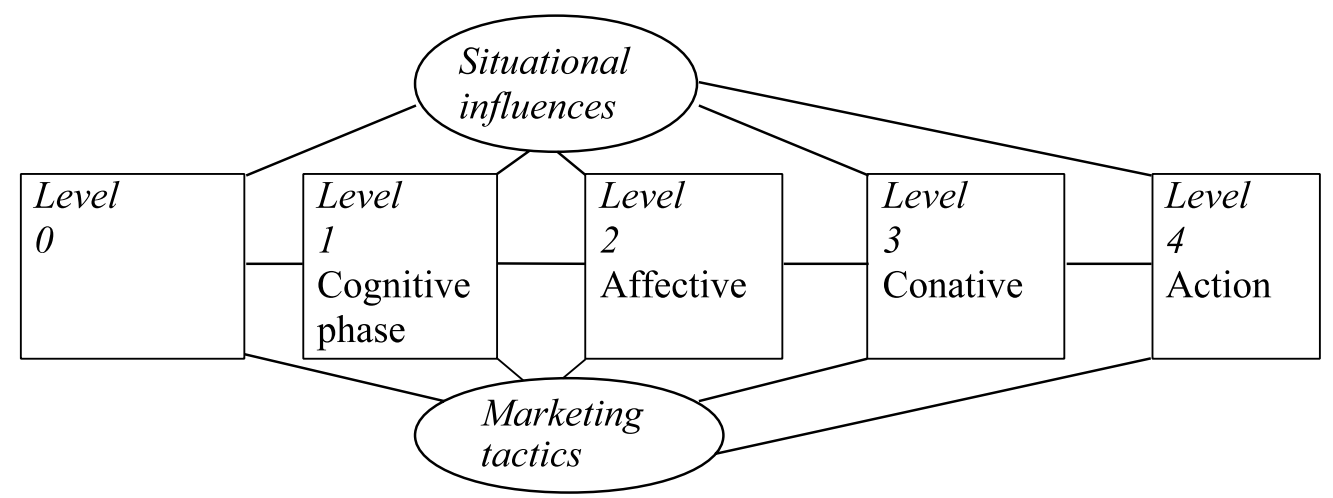

Figure 1 Hypothesis 1

the missing link. This phase is different to the other phases as it involves commitment to overcome situational constraints that may intervene in a purchase decision.

\section{HYPOTHESIS}

This research aims to test the hypothesis that customer loyalty develops in a sequential manner through four phases (see Figure 1).

Hypothesis 1: There are four distinct phases in the development of a customer's loyalty towards a product or service: cognitive, affective, conative and action.

Figure 1 illustrates Oliver's model of the development of customer loyalty. ${ }^{25}$ Despite marketing tactics and situational influences, the customer chooses his or her preferred brand on each occasion. The customer begins at Level 0, when he or she holds no information or has not developed an attitude towards the product or service. The cognitive dimension is Level 1 . The customer has a set of beliefs that may include that the product or service is superior to other brands within that category.

Level 2 is the affective dimension. This phase is characterised by customers developing an unfavourable or favourable attitude towards the product or service. This precedes the third phase, the conative dimension. This relates to individuals' intentions to behave and whether they will repurchase. The next phase relates to actual behaviour and is referred to as action. Based on this framework it is hypothesised that the development of loyalty is dependent upon a customer passing through each of the four phases.

Each phase within the development of loyalty has a number of characteristics or dimensions, which act as either sustainers (attracting the customer to stay) or vulnerabilities (pulling the customer towards a substitute). The following discussion is based on existing validated research, which identifies the validity of the first three phases ${ }^{26,27}$ and the characteristics associated within each. ${ }^{28,29}$ This research aims to validate the fourth and final phase within the framework.

\section{COGNITIVE PHASE}

The cognitive phase is associated with informational determinants or brand beliefs. These relate to individuals' perceptions of the cost, quality and benefits of the product or service that act as either 'sustainers' or 'vulnerables' or push and pull factors (see Table 1). Dick 
Table 1: Phases in the development of customer loyalty and associated characteristics ${ }^{54}$

\begin{tabular}{|c|c|c|c|}
\hline Phase & Antecedents & Sustainers & Vunerabilities \\
\hline Cognitive & $\begin{array}{l}\text { Accessibility } \\
\text { Confidence } \\
\text { Centrality } \\
\text { Clarity }\end{array}$ & $\begin{array}{l}\text { Cost } \\
\text { Benefits } \\
\text { Quality }\end{array}$ & $\begin{array}{l}\text { Cost } \\
\text { Benefits } \\
\text { Quality }\end{array}$ \\
\hline Affective & $\begin{array}{l}\text { Emotions } \\
\text { Moods } \\
\text { Primary } \\
\text { Satisfaction }\end{array}$ & $\begin{array}{l}\text { Satisfaction } \\
\text { Involvement } \\
\text { Affect, Liking Preference } \\
\text { Cognitive consistency }\end{array}$ & $\begin{array}{l}\text { Dissatisfaction } \\
\text { Persuasion } \\
\text { Trial }\end{array}$ \\
\hline Conative & $\begin{array}{l}\text { Switching costs } \\
\text { Sunk costs }\end{array}$ & $\begin{array}{l}\text { Commitment } \\
\text { Cognitive consistency }\end{array}$ & $\begin{array}{l}\text { Persuasion } \\
\text { Trial }\end{array}$ \\
\hline$\stackrel{\downarrow}{\text { Action }}$ & $\begin{array}{l}\text { Inertia } \\
\text { Sunk costs }\end{array}$ & $\begin{array}{l}\text { Persuasion } \\
\text { Trial }\end{array}$ & $\begin{array}{l}\text { Persuasion } \\
\text { Trial }\end{array}$ \\
\hline
\end{tabular}

and Basu identify a further four dimensions or antecedents to loyalty within the cognitive phase accessibility, confidence, centrality and clarity - as important indicators of loyalty. ${ }^{30}$ Attitude accessibility acts as a guide to behaviour ${ }^{31}$ and consequently has relevance to the action phase in addition to the cognitive phase.

Accessibility is the ease with which an attitude can be retrieved. It is hypothesised that the easier the retrieval of the brand the more likely it is that loyalty exists. ${ }^{32}$

Confidence relates to the level of certainty associated with an attitude and its evaluation. Confidence, similar to accessibility, is associated with attitude and behaviour consistency. ${ }^{33}$ Research shows that the degree of consumer confidence may be influenced by the source of the brand information. For example, individuals will perceive information from friends and relatives to be more credible and consistent than information from impersonal sources. ${ }^{34}$

Centrality is the degree to which an attitude towards a brand is related to the individual's value system. This is conceptualised by customers' sense of belonging or involvement with the brand. This dimension has relevance for both the cognitive and affective phases of loyalty development. Dick and Basu suggest that an example of centrality is the relationship between store image and self-image. ${ }^{35}$ Centrality or central attitudes are important for a number of reasons. First, they belong to an individual and provide a sense of intimacy with the brand. Secondly, centrality typically involves strong affective responses that are relatively distinct and tend to be frequently activated. Conversely, attitudes that are not related to a consumer's value system are less stable and more sensitive to persuasion and observed loyalty may be more available. Research also indicates that central attitudes relate to behaviour through their impact on accessibility. ${ }^{36}$ Dick and Basu suggest that central attitudes evoke strong emotions such as loyalty and that to change this status would require significant persuasion. ${ }^{37}$

Cognitive clarity is the last cognitive dimension or antecedent cited by Dick and Basu. ${ }^{38}$ An attitude is well defined or clear when an individual finds alternative attitudes towards other products or services within the same category and undefined when many alternatives are acceptable. A well-defined attitude may influence behaviour more than an 
undefined attitude. ${ }^{39}$ Clarity has also been viewed as a keenness of discrimination, which is driven by ego involvement and social judgment. Dick and Basu suggest that the effect of clarity on loyalty could be viewed in terms of differentiating between a competitive set that consumers invoke to reduce level of choice. $^{40}$

\section{AFFECTIVE PHASE}

Within the affective dimension, issues relating to satisfaction, liking, preference and cognitive consistency have been identified. ${ }^{41}$ Once the product or service has been tried, the customer may evaluate his or her experience. Decisions may be made on the level of satisfaction, how much he or she likes the product or service, the extent of his or her preference and his or her level of cognitive consistency or certainty. Dick and Basu add antecedents of emotions, moods, primary affect and satisfaction to the affective phase. ${ }^{42}$

Emotions are defined as immense states of arousal which are focused on specific targets. ${ }^{43}$ Emotions are suggested to act as better behavioural indicators than cognitive evaluations, particularly when behaviour has become habitual. ${ }^{44}$ At this point past experiences become relatively free of cognitive evaluations. Moods are suggested to be less intense than emotions and consequently less disruptive and stable. Individuals in a good mood are expected to recall more positive items than in a neutral mood. Dick and Basu suggest that moods may affect loyalty through accessibility but may be manipulated through advertising extensions, favourable surroundings that induce good moods. ${ }^{45}$

Primary affect is conceptualised as physiological in nature and often driven by direct experience such as taste. ${ }^{46}$ The presentation of an attitude object, such as an aroma or fragrance, may lead to primary responses that are independent of cognition. Satisfaction is the last of the affective antecedents proposed by Dick and $\mathrm{Basu}^{47}$ and is considered to be key to loyalty development. ${ }^{48,49}$ Satisfaction relates to a consumer's post-purchase response to a brand and is believed to occur through a matching of expectations and perceived performance. The resulting satisfaction or dissatisfaction is considered to act as an antecedent to loyalty. ${ }^{50}$ Dick and Basu however, highlight the elements that will cause vulnerability during the affective phase dissatisfaction, persuasion and trial of substitutes. $^{51}$

\section{CONATIVE PHASE}

The third phase is characterised by the level of the consumer's commitment or intention to buy and how stable or consistent his or her beliefs (cognitions) are about the product or service. Dick and Basu view conative antecedents to three distinct aspects, switching costs, sunk costs and expectations. ${ }^{52}$ Switching costs also appear in various consumer choice settings including personal banking where the perceived costs of changing account have potential financial penalties and additional consumer learning. There are also psychological dimensions associated with switching. This is particularly relevant to the services sector where personal relationships are developed within the service encounter. Sunk costs have potential for profound effects on consumer purchases. Studies suggest that despite their economic irrelevance sunk costs increase the likelihood of repeat purchases. This has been proven to some extent within the loyalty programme debate, where, for example, airline passengers often choose longer routes in order to accumulate additional frequent 
flyer miles ${ }^{53}$ The vulnerable elements at the conative phase that will test the customer's loyalty include persuasion and trial of substitutes.

\section{ACTION PHASE}

The last phase, which Oliver has added to existing models, is the action phase characterised by inertia and sunk costs. This is the differentiating phase of this model, in that previous research has tested either behaviour or attitudes independently rather than jointly. Inertia relates to a customer's contentment with a product or service to the degree that his or her information-seeking relating to substitutes has diminished. Sunk costs remain important at this phase. Persuasion and trial remain the forces that will challenge the customer's loyalty and its existing and future development.

\section{MEDIATING FACTORS}

The mediating factors of sustainers and vulnerabilities allow modelling of the continued influence of competitors, advertising, service failure and other external influences that sustain or make an existing customer vulnerable. The key issue is that as customers progress through the phases of loyalty development, the sustainers and vulnerability elements are hypothesised to change, reflecting the customer's level of involvement. Once a customer has found a service that he or she enjoys and continues to use, results indicate less concern with seeking alternatives and reduced response to advertising or competitive threats. ${ }^{55}$ Dick and Basu discuss the influence of social norms and situational factors to repeat patronage. ${ }^{56}$ The issue of social norms relates to the individual's perception of what significant others think he or she should or should not perform and his or her motivation to comply with such referents. Situational factors may affect loyalty in several ways including the actual or perceived opportunity for engaging in attitude-consistent behaviour. Instances may include when the preferred brand is not available or effective promotions that might increase the salience of one brand over another. Oliver suggests that one way to test these issues within the four-phase model is to construct a scale, which taps into each of the phases, their characteristics and mediating factors. Scales are often used within the measurement of various issues within marketing, including materialism ${ }^{57}$ and group influence. ${ }^{58}$

\section{METHODOLOGY}

The preceding literature review highlights essential research in the theoretical outlining of the construct of loyalty, its antecedents, characteristics and phases. Literature has also focused on measuring the effectiveness of loyalty programmes. ${ }^{59-61}$ While this contribution has created interest and discussion in the general area of measuring the effectiveness of frequency-based loyalty programmes, it has achieved little in determining the nature of customer loyalty and consequences for its management. For the purposes of this research, however, customer loyalty is as defined by Oliver 'a deeply held commitment to rebuy or repatronise a preferred product or service consistently in the future, thereby causing repetitive same-brand or same brand-set purchasing, despite situational influences and marketing efforts having the potential to cause switching behaviour'. ${ }^{62}$ Based on this definition of the construct and existing research, the scale will be constructed based on Oliver's four-phase model, which aims to test four individual phases, characteristics and mediating factors. 
Development of the scale required a review of existing scales. Within the context of customer loyalty, there appears to be an absence of a validated and reliable scale to measure the development of that loyalty. Many studies exist which explore particular aspects of customer loyalty, generally either behavioural or attitudinal in nature rather than composite. Baldinger and Ruben completed a study which tested the link between attitude and behaviour within the context of brand loyalty. ${ }^{63}$ This provided useful longitudinal data on brand loyalty and relationship duration. The study did not, however, outline the phases, characteristics and mediating factors in the development of customer loyalty.

In consideration of the characteristics within Oliver's model, a scale to measure loyalty development should include items that facilitate the measurement of four phases, cognitive, affective, conative and action. As shown in Table 1, these phases have a number of related characteristics including involvement, commitment, switching, quality and loyalty proneness. The scale includes attitude statements that are negatively scored to allow for the testing of 'sustainers' and 'vulnerabilities'.

A number of existing scales was reviewed and a pool of 122 items generated (Oliver suggested the use of these existing scales in the development of customer loyalty scale). Raju's scale measured loyalty within the 'exploratory tendencies in consumer behaviour scales (ETCBS) $\cdot{ }^{64}$ Oliver's scale measured satisfaction. ${ }^{65}$ Parasuraman et al. measured service quality using the SERVQUAL scale $^{66}$. Beatty et al.'s measure involved commitment, based on the assumption that commitment is similar to loyalty. ${ }^{67}$ This scale included items which reflected ego involvement, purchase involvement and brand commitment. While each of these scales represented dimensions of loyalty, none was developed to measure the development of loyalty. Items from these scales and others were, however, used to develop the loyalty scale. This approach had the advantage of using existing validated and reliable scales, which would enhance the development of the loyalty scale.

In addition, a combination of validity and reliability measures was employed in the development of the scale. The first of these required a panel of experts to trim and refine scale items. The panel consisted of five experts: three academics who specialised in service quality, customer loyalty and services marketing; and two practitioners, one of whom is responsible for managing a customer loyalty programme.

The number of items were trimmed and refined to 28 . The 28 items were piloted for face validity and reliability (see Table 2). The scale items aimed to test the cognitive, affective, conative and action phases of customer loyalty. There were six items tapping the cognitive phase $(\mathrm{C})$, seven tapping the affective phase (A), nine tapping the conative phase $(\mathrm{CO})$ and six tapping the action phase (AC). One anticipated outcome of the pilot study was the reduction or refinement of items within the scale. The scale was piloted among a sample of 250 restaurant diners who belong to a dining club. The aim of this was to allow initial purification and, if necessary, rearranged in disconfirmation style phrases. Further tests included estimates of internal consistency reliability for the four phases and characteristics and principal component analysis to test dimensionality and loadings of the data set. ${ }^{68,69}$ The checks lead to a final pool of items.

\section{SAMPLE DEVELOPMENT}

The sample was drawn at random from a university training restaurant diners club, 
Table 2: Pilot loyalty scale

\begin{tabular}{|c|c|c|}
\hline C.1 & $\begin{array}{l}\text { I understand the features of Restaurant } X \text { well enough to evaluate it against } \\
\text { other restaurants }\end{array}$ & 1234567 \\
\hline C.2 & $\begin{array}{l}\text { It is important that when choosing to eat out, I make the right choice of } \\
\text { restaurant }\end{array}$ & 1234567 \\
\hline A.3 & Restaurant $\mathrm{X}$ is a restaurant that interests me & 1234567 \\
\hline C.4 & When deciding on a restaurant, I am not interested in bargain-seeking & 1234567 \\
\hline C.5 & $\begin{array}{l}\text { When choosing a restaurant, I compare prices of different restaurants to be } \\
\text { sure I get the best value for money }\end{array}$ & 1234567 \\
\hline C.6 & Restaurant $\mathrm{X}$ has up-to-date equipment & 1234567 \\
\hline C.7 & Restaurant X's facilities are visually appealing & 1234567 \\
\hline A.8 & Restaurant $X$ is exactly what I need from a restaurant & 1234567 \\
\hline A.9 & $\begin{array}{l}\text { Restaurant } X \text { as a choice of restaurant has not worked out as well as I } \\
\text { thought it would }\end{array}$ & 1234567 \\
\hline AC.10 & $\begin{array}{l}\text { If I could do it over again, l'd choose an alternative restaurant to } \\
\text { Restaurant } X\end{array}$ & 1234567 \\
\hline Co.11 & I truly have enjoyed dining in Restaurant $X$ & 1234567 \\
\hline A.12 & Restaurants should not be expected to give customers individual attention & 1234567 \\
\hline A.13 & Restaurant $X$ is a restaurant that I could talk about for a long time & 1234567 \\
\hline A.14 & I have a preference for Restaurant $\mathrm{X}$ in this locality & 1234567 \\
\hline Co.15 & Restaurant $\mathrm{X}$ is more than a mere restaurant & 1234567 \\
\hline Co.16 & $\begin{array}{l}\text { I would try an alternative restaurant if it was } 25 \% \text { less expensive than } \\
\text { Restaurant } X\end{array}$ & 1234567 \\
\hline Co.17 & $\begin{array}{l}\text { I would try an alternative restaurant if the alternative restaurant offered } \\
\text { increased facilities than Restaurant } X\end{array}$ & 1234567 \\
\hline Co.18 & I would change restaurant if the alternative offered increased status & 1234 \\
\hline Co.19 & I would change restaurant if the alternative's staff were more friendly & 1234567 \\
\hline AC. 20 & $\begin{array}{l}\text { When I see a new restaurant somewhat different from the usual, I } \\
\text { investigate it }\end{array}$ & 1234567 \\
\hline AC.21 & I usually dine in the same restaurant within a locality & 1234567 \\
\hline A.22 & Dining in Restaurant $X$ says a lot about who I am & 1234567 \\
\hline Co.23 & I care a lot about Restaurant $X$ & 1234567 \\
\hline Co.24 & I consider myself to be highly loyal to Restaurant $X$ & 1234567 \\
\hline Co.25 & I would get tired of eating in Restaurant $X$ every time I eat out & 1234567 \\
\hline AC.26 & When I go to a restaurant, I feel it is safer to order dishes I am familiar with & 1234567 \\
\hline AC. 27 & If I like a restaurant, I rarely switch from it just to try something different & 1234567 \\
\hline AC.28 & I get bored with buying the same brands even if they are good & 1234567 \\
\hline
\end{tabular}

$1=$ strongly disagree, $2=$ moderately disagree, $3=$ disagree, $4=$ no opinion, $5=$ agree, $6=$ moderately agree, $7=$ strongly agree, $\mathrm{C}=$ cognitive item, $\mathrm{A}=$ affective item, $\mathrm{CO}=$ conative item, $\mathrm{AC}=$ action

which consisted of a population of 438 customers who had previously used the university training restaurant and were members of the diners club. The population represented convenience to the researchers. Further tests of validity and reliability will take place in other service sectors to ensure that the loyalty scale is operational in a variety of contexts. The operational nature of the database resulted in customers who were at differing phases within their development of loyalty. The university training restaurant diners club had competitors on campus and within a short walking distance, so customers had a range of restaurants from which to choose. The questionnaire, which included the pilot loyalty scale, was administered by post in the form of a self-completion questionnaire in January, 2001. Dillman's total design method was employed to maximise the response rate. Incentives in the form of sponsored prizes from a restaurant were offered to encourage prompt return. ${ }^{70}$

\section{ANALYSIS}

H1: The results of the PCA and reliability analysis indicate that there is strong evidence to support Hypothesis 1 . The following analysis shows that the items used to measure each stage within the development of loyalty are valid and reliable. 
The data were coded and organised before any analysis was carried out. This included inputting the data into an SPSS Version 9 file, screening for errors and recoding directional questions to ensure all data were pointing in the same direction. Missing data were also coded. Each variable was labelled, defined and organised numerically to allow for ease of analysis.

Two hundred and ten usable questionnaires were returned, representing a response rate of 47.9 per cent. The distribution of gender within the sample was 31.4 per cent male, 66.7 per cent female. Gender was not specified as a variable for this stage of the research and therefore is perceived not to constitute a bias. The age distribution among the sample was spread evenly, with a clustering of respondents aged between 40-49 and 50-59 categories (48 per cent).

The analysis sought to test Hypothesis I and the validity and reliability of the pilot loyalty scale. The validity of the pilot scale was tested using principal component analysis (PCA) SPSS Version 9. PCA attempts to identify underlying variables, or components, that explain the pattern of correlations within a set of observed variables. ${ }^{71} \mathrm{PCA}$ is a tool to bring order to the way in which data are perceived, by determining which data are related and which are not. ${ }^{72}$ PCA is based on correlation coefficients and generates a number of components, which consist of items. This is an exploratory type of analysis, which establishes the relationship between various variables without determining the extent to which the results fit a particular model. The value of this technique is that it allows identification of underlying components and what the components represent conceptually. PCA may be used to eliminate items that exhibit a low inter-item correlation.
In order to use PCA, the data must conform to a number of assumptions. The first assumption relates to the data being at interval level. The researcher considers the data within the research to be at ordinal level as it is impossible to rank accurately an individual's strength of attitude against that of another individual, despite a numeric value being attached to both. It is argued, however, that empirical evidence exists to support the treatment of ordinal variables as if they conform to interval scales. ${ }^{73,74}$ Secondly, the data must have significant inter-item correlations that are all above 0.3 , which means that the data are factorable. The third test for identifying whether a set of variables is suitable is Bartlett's test of sphericity (factor analysis) that tests whether the correlation matrix is an identity matrix, which would indicate that the factor model is inappropriate. The result of the Bartlett's test was significant which renders the data factorable.

Table 3 highlights the results of the PCA of the pilot loyalty scale. The Table shows the total variance explained by the nine principal components in the pilot loyalty scale. Kaiser's criterion is the main criterion used for deciding the number of components to be retained. ${ }^{75}$ The test may be applied when data consist of less than 30 variables, where the average communality is greater than or equal to 0.70 or when the number of subjects is greater than 250. This research had 28 variables and 210 subjects. The average communality was 0.75 . Therefore, the data met the assumptions of Kaiser's criterion.

Based on Kaiser's criterion the PCA has nine components, which have an eigenvalue of over one, the first four accounting for the greatest amount of variance.

The second method for deciding which components to retain is the scree 
Table 3: Total variance explained of pilot loyalty scale

\begin{tabular}{|c|c|c|c|c|c|c|c|c|c|}
\hline \multirow[b]{2}{*}{ Component } & \multicolumn{3}{|c|}{ Initial eigenvalues } & \multicolumn{3}{|c|}{$\begin{array}{l}\text { Extraction sums of } \\
\text { squared loadings }\end{array}$} & \multicolumn{3}{|c|}{ Rotation sums of squared loadings } \\
\hline & Total & $\begin{array}{l}\% \text { of } \\
\text { variance }\end{array}$ & $\begin{array}{l}\text { Cumulative } \\
\%\end{array}$ & Total & $\begin{array}{l}\% \text { of } \\
\text { variance }\end{array}$ & $\begin{array}{l}\text { Cumulative } \\
\%\end{array}$ & Total & $\begin{array}{l}\% \text { of } \\
\text { variance }\end{array}$ & $\begin{array}{l}\text { Cumulative } \\
\%\end{array}$ \\
\hline 1 & 5.934 & 21.193 & 21.193 & 5.934 & 21.193 & 21.193 & 3.855 & 13.769 & 13.769 \\
\hline 2 & 2.791 & 9.969 & 31.162 & 2.791 & 9.696 & 31.162 & 3.590 & 12.820 & 26.590 \\
\hline 3 & 2.440 & 8.715 & 39.876 & 2.440 & 8.715 & 39.876 & 3.112 & 11.115 & 37.705 \\
\hline 6 & 1.661 & 5.930 & 60.272 & & & & & & \\
\hline 7 & 1.583 & 5.654 & 65.925 & & & & & & \\
\hline 8 & 1.302 & 4.650 & 70.576 & & & & & & \\
\hline 9 & 1.230 & 4.394 & 74.969 & & & & & & \\
\hline 10 & 0.982 & 3.507 & 78.476 & & & & & & \\
\hline 11 & 0.828 & 2.958 & 81.434 & & & & & & \\
\hline 17 & 0.396 & 1.413 & 93.696 & & & & & & \\
\hline 18 & 0.383 & 1.369 & 95.065 & & & & & & \\
\hline 19 & 0.296 & 1.057 & 96.123 & & & & & & \\
\hline 20 & 0.264 & 0.944 & 97.067 & & & & & & \\
\hline 21 & 0.209 & 0.745 & 97.812 & & & & & & \\
\hline 22 & 0.178 & 0.636 & 98.447 & & & & & & \\
\hline 23 & 0.141 & 0.503 & 98.950 & & & & & & \\
\hline 24 & 0.105 & 0.375 & 99.325 & & & & & & \\
\hline 25 & $8.165 \mathrm{E}-02$ & 0.292 & 99.617 & & & & & & \\
\hline 26 & 4.799E-02 & 0.171 & 99.788 & & & & & & \\
\hline 27 & 3.423E-02 & 0.122 & 99.911 & & & & & & \\
\hline 28 & $2.499 \mathrm{E}-02$ & $8.925 \mathrm{E}-02$ & 100.000 & & & & & & \\
\hline
\end{tabular}

Extraction method: Principal component analysis

test. Figure 2 shows the scree plot with descending variance accounted for by the nine initially extracted components. The plot shows a break between the steep slope of the initial factors (or components) and a gentle one for the remainder, implying that the latter are less important. The factors to be retained are those which lie before the point at which the eigenvalues seem to level off. In Figure 2 this occurs after factor nine.

Table 4 shows the inter-item correlations of the scale, in addition to the number of components generated by the PCA. No items had a correlation of 0.3 or less across any of the components, therefore none was rejected at this stage. The items were examined across each component to identify which component the item correlated highest against and to prevent duplication of items within different components. For example, item 1 (labelled features), correlated highest on component 7 . Therefore, in the reliability analysis, item 1 was tested with all other component 7 items.

Reliability analysis was then carried out to ensure the items in each component were reliable. ${ }^{76}$ Reliability analysis has two goals. The first goal is to ensure the reliability of the scale and the second is to increase the reliability of the scale. The most popular test for reliability analysis is Cronbach's alpha. The closer that Cronbach's alpha is to one, the higher the reliability of the scale. Scores over 0.8 are considered to be acceptable for most purposes. ${ }^{77}$ The reliability of components 1 and 2, which have the greatest number of items loading, 


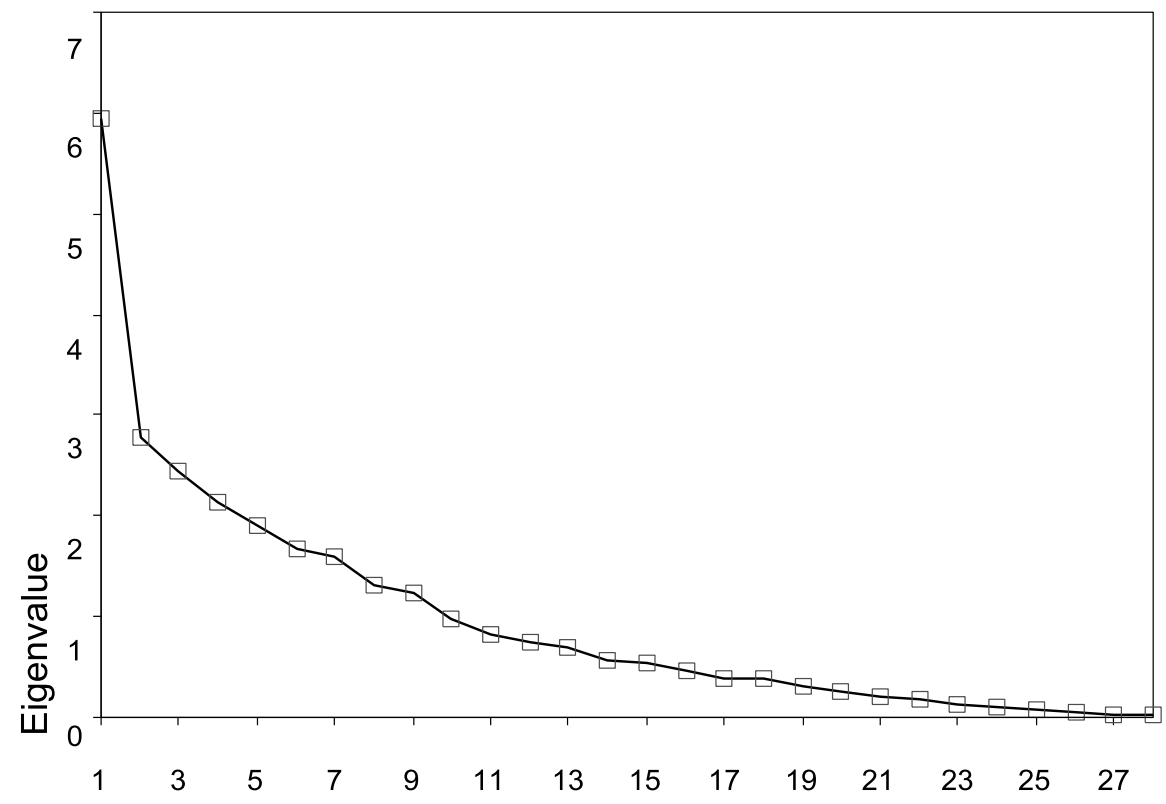

Component Number

Figure 2 Scree plot of pilot loyalty scale

$0.6971-(-) 0.8117$ (the negative value has no meaning in this context). By removing item 15 the reliability score of the scale increased, which showed a low correlation and therefore low reliability.

\section{MANAGERIAL IMPLICATIONS}

The research highlights a number of managerial implications. First, the scale can measure the development of loyalty. Validity and reliability tests highlight that the scale is valid and reliable. Once the scale is complete it may be used to identify individual levels of loyalty. These data may be used to develop strategies for specific levels of loyalty and, in conjunction with market research that organisations may have, to build profiles, particularly in relation to frequency and length of usage. For example, managers would be able to correlate switching behaviour with level of loyalty within their organisation. The scale may also be used to track individuals' loyalty over time, to identify diminishing and increasing levels and explore the underlying reasons.

Managers may also use the data to segment customers into low, medium and high levels of loyalty in order that they may research specific issues relating to each level; for example, what service issues would make a customer who has a high level of loyalty stay loyal, or what would make a customer who has a low level of loyalty become more loyal. The rationale of sustaining and developing loyalty among customers is to reduce vulnerability towards competitors' strategies.

\section{FUTURE RESEARCH}

This research forms the basis of a larger research project aiming to test Oliver's multi-phase model of customer loyalty 


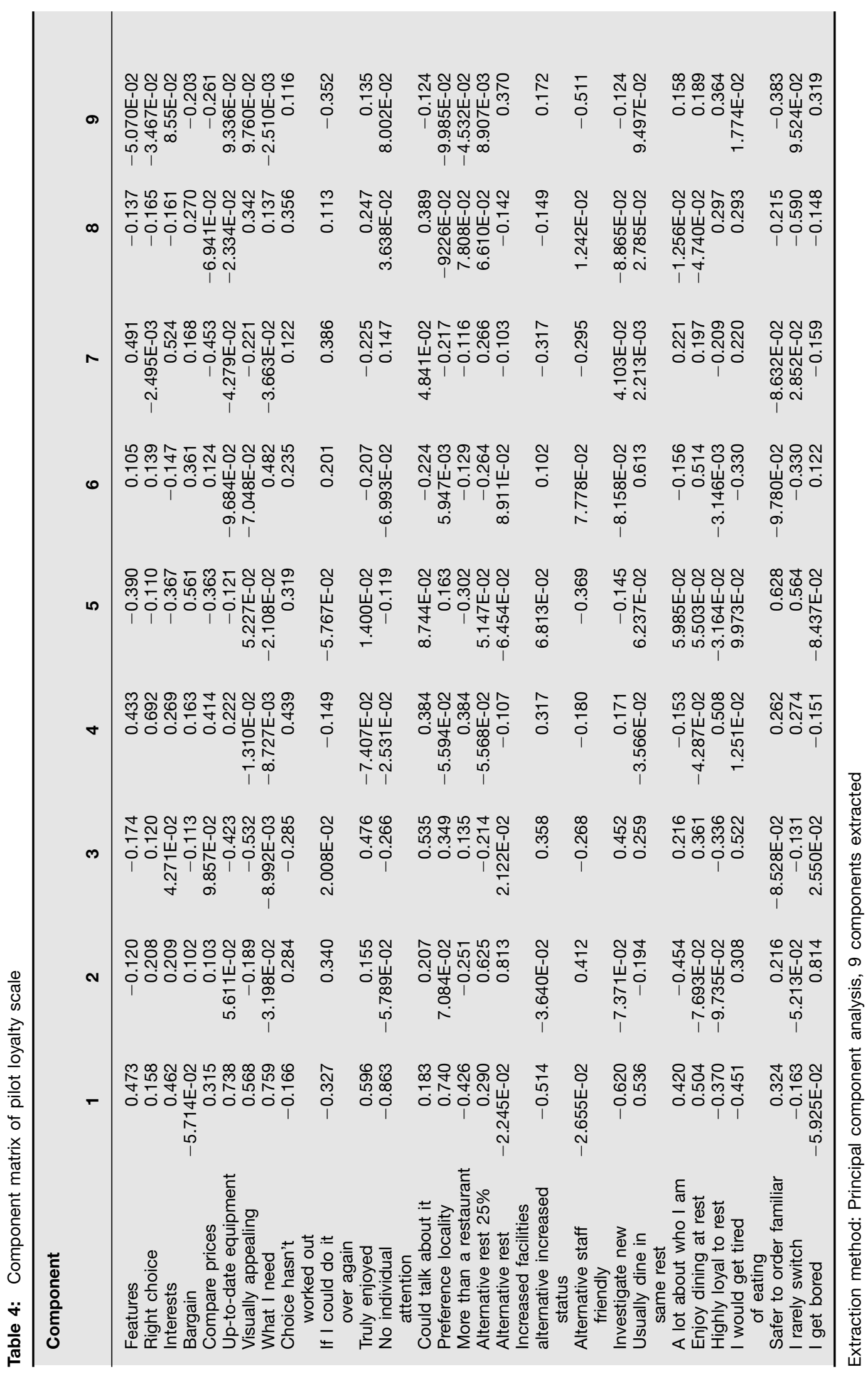


measurement. ${ }^{78}$ The pilot study discussed is the first stage in testing the validity and reliability of the scale presented. The next stage in the project involves a large-scale administration of the scale to a sample of customers within a different service sector, which will allow further testing of the scale and development of a scoring system to identify different levels of loyalty among customers.

\section{CONCLUSION}

The findings of this research contribute to a growing body of knowledge in relation to the management of customer loyalty. The strength of this research is that it contributes a valid and reliable scale for the measurement of customer loyalty. Previously, the main method for profiling customers' loyalty used behavioural data. The advantage of this scale is that it uses attitudinal and behavioural data. The loyalty scale offers practitioners a range of possibilities in relation to identifying and managing customer loyalty within organisations. The authors conclude that an organisation's long-term success in a market is determined by its ability to expand and maintain a significant level of loyalty among its customers.

\section{References}

1 Dick, A. S. and Basu, K. (1994) 'Customer loyalty: Toward an integrated conceptual framework', Journal of the Academy of Marketing Science, Vol. 22, Winter, pp. 99-113.

2 Oliver, R. (1997) 'Loyalty and profit: Long term effects of satisfaction', in satisfaction', in Oliver, R. (ed.) 'Satisfaction: A behavioural perspective on the consumer', McGraw-Hill Companies, Inc.

3 Oliver, R. (1999) 'Whence consumer loyalty?', Journal of Marketing, Vol. 63, pp. 33-44.

4 Oliver (1997) op. cit.

5 Oliver (1999) op. cit.

6 Dwyer, F. R, Schurr, P. H. and Oh, S. (1987) 'Developing buyer and seller relationships', Journal of Marketing, No. 51, April, pp. 11-27.

7 Palmer, A. J. and Bejou, D. (1994) 'Buyer-seller relationships: A conceptual model and empirical investigation', Journal of Marketing Management, Vol. 10, No. 6, pp. 495-512.

8 Shoemaker, S. and Lewis, R. C. (1999) 'Customer loyalty: The future of hospitality marketing',

International Journal of Hospitality Management, Vol. 18, pp. $345-370$.

9 Oliver (1997) op. cit.

10 Oliver (1999) op. cit.

11 Dick and Basu (1994) op. cit.

12 Palmer, A. J. (1996) 'Integrating brand development and relationship marketing', Journal of Retailing and Consumer Services, Vol. 3, No. 3, pp. 1-6.

13 O'Malley, L. (1998) 'Can loyalty schemes really build loyalty', Marketing Intelligence and Planning, Jan-Feb, Vol. 16, No. 1, pp. 1-7.

14 Shoemaker and Lewis (1999) op. cit.

15 Jacoby, J. and Kyner, B. (1973) 'Brand loyalty versus repeat purchasing behaviour', Journal of Marketing Research, February, pp. 1-9.

16 Oliver (1999) op. cit.

17 Jacoby, J. and Chesnut, R. W. (1978) 'Brand loyalty measurement and management', Wiley, New York.

18 Oliver (1999) op. cit.

19 Jacoby and Kyner (1973) op. cit.

20 Dick and Basu (1994) op. cit.

21 Oliver (1997) op. cit.

22 Oliver (1999) op. cit.

23 Oliver (1997) op. cit.

24 Oliver (1999) op. cit.

25 Ibid.

26 Fishbein, M. and Ajzen, I. (1972) 'Attitudes and opinions', Annual Review of Psychology, Vol. 23, pp. 487-544.

27 Jacoby and Chesnut (1978) op. cit.

28 Dick and Basu (1994) op. cit.

29 Oliver (1997) op. cit.

30 Dick and Basu (1994) op. cit.

31 Fazio, R. H., Powell, M. C. and Williams, C. J. (1989) 'The role of attitude accessibility in the attitude-to-behaviour process', Journal of Consumer Research, Vol. 16, December, pp. 280-288.

32 Fazio et al. (1989) op. cit.

33 Howard, J. A. and Sheth, J. N. (1969) 'The theory of buyer behaviour', John Wiley and Sons, New York.

34 Bennett, P. D. and Kassarjian, H. H. (1972) 'Consumer behaviour', Prentice-Hall, Inc., Englewood Cliffs, New Jersey.

35 Dick and Basu (1994) op. cit.

36 Fishbein and Ajzen (1972) op. cit.

37 Dick and Basu (1994) op. cit.

38 Ibid.

39 Sherif, J., Musafer, R. and Nebergall, D. (1965) 'Attitude and attitude change: The social judgement involving approach', Yale University Press, New Haven, Conn.

40 Dick and Basu (1994) op. cit.

41 Oliver (1997) op. cit.

42 Dick and Basu (1994) op. cit.

43 Mandler, G. and Sarason, S. B. (1952) 'A study of anxiety and learning', Journal of Abnormal Social Psychology, Vol. 47, pp. 166-173.

44 Fazio et al. (1989) op. cit. 
45 Dick and Basu (1994) op. cit.

46 Fishbein and Ajzen(1972) op. cit.

47 Dick and Basu (1994) op. cit.

48 Oliver (1997) op. cit.

49 Oliver (1999) op. cit.

50 Bitner, M. J. (1990) 'Evaluating service encounters: The effects of physical surroundings and employee responses', Journal of Marketing, Vol. 54, April, pp. 69-82.

51 Dick and Basu (1994) op. cit.

52 Ibid.

53 O’Malley (1998) op. cit.

54 Oliver (1997) op. cit.

55 Newman, J. W. and Werbel, R. A. (1973)

'Multivariate analysis of brand loyalty for major household appliances', Journal of Marketing Research, Vol. 10, pp. 404-409.

56 Dick and Basu (1994) op. cit.

57 Belk, R. W. (1975) 'Situational variables in consumer behaviour', Journal of Consumer Research, December, pp. 157-164.

58 Bearden, W. O., Netemeyer, R. G. and Mobley, M. F. (1993) 'Handbook of marketing scales: Multi-item measures for marketing and consumer behavior research', Sage Publications Inc., California.

59 O’Malley (1998) op. cit.

60 Taylor, T. B. (1998) 'Better loyalty measurement leads to business solutions', Marketing News, 26th October, p. 41.

61 Martensen, A., Gronholdt, L. and Kristensen, K. (2000) 'The drivers of customer satisfaction and loyalty: Cross-industry findings from Denmark', Total Quality Management, Vol. 4, No. 6, pp. 544-553.

62 Oliver (1999) op. cit.

63 Baldinger, A. L. and Ruben, J. (1996) 'Brand loyalty: The link between attitude and behaviour', Journal of Advertising Research, November-December, pp. 22-34.

64 Raju, P. S. (1980) 'Optimal satisfaction level: Its relationship to personality, demographics, and exploratory behaviour', Journal of Consumer Research, Vol. 7, December, pp. 272-282.

65 Oliver (1997) op. cit.

66 Parasuraman, A., Zeithaml, A. and Berry, L. L. (1988) 'SERVQUAL: A multiple-item scale for measuring consumer perceptions of service quality', Journal of Retailing, Vol. 64, No. 1, pp. 12-40.

67 Beatty, S. E., Kahle, L. R. and Homer, P. (1988)

'The involvement-commitment model: Theory and implications', Journal of Business Research, Vol. 16, March, pp. 149-167.

68 Robinson, J. P., Shaver, R. and Wrightsman, L. S. (1991) 'Criteria for scale selection and evaluation', in Robinson, J. P. et al. (eds) 'Measures of personality and social psychological attitudes', The Academic Press, San Diego, CA, pp. 1-15.

69 Bearden et al. (1993) op. cit.

70 De Vaus, D. A. (1996) 'Surveys in social research', 4th edition, UCL Press Ltd., London.

71 SPSS for Windows Glossary.

72 Tull, D. S. and Hawkins, D. I. (1990) 'Marketing research: Measurement \& method', 5th edition, Macmillan Publishing Company, New York.

73 Labovitz, S. (1967) 'Some observations on measurement and statistics', Social Forces, Vol. 46, December, pp. 151-160.

74 Labovitz, S. (1970) 'The assignment of numbers to rank order categories', American Sociological Review, Vol. 35, pp. 315- 324.

75 Bryman, A. and Cramer, D. (1997) 'Quantitative data analysis with SPSS for Windows: A guide for social scientists', Routledge, London.

76 Bearden, W. O., Netemeyer, R. G. and Mobley, M. F. (1993) 'Handbook of marketing scales: Multi-item measures for marketing and consumer behavior research', Sage Publications Inc., California.

77 Bryman and Cramer (1997) op. cit.

78 Oliver (1997) op. cit. 